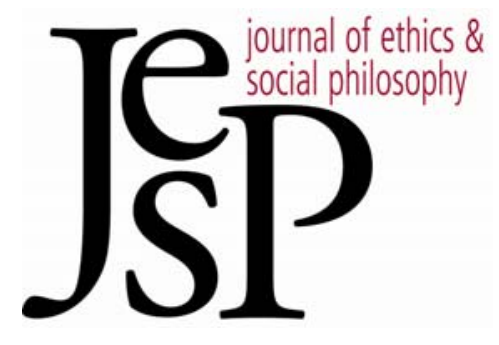

\title{
STRICT LIABIIIT AND The MitigATION OF MORAL LUCK
}

BY GREGORY C. KEATING

JOURNAL OF ETHICS\& SOCIAL PHIILSOPHY

VoL. 2, No. 1| AUGUST 2006

URL: WWW.JESP.ORG

COPYRIGHT (C) GREGORY C. KEATING 2006 
JOURNAL OF ETHICS \& SOCIAL PHILOSOPHY | VOL. 2, No. 1

STRICT LIABILITY AND THE MITIGATION OF MORAL LUCK

Gregory C. Keating

STRICT LIABILITY AND THE MITIGATION OF MORAL LUCK

Gregory C. Keating ${ }^{1}$

$\mathrm{T}$

HE PHENOMENON OF accidental injury appears in both Bernard Williams' and Thomas Nagel's foundational articles on the problem of "moral luck."2 That appearance is hardly surprising: Liability for accidental injury turns quite heavily on "elements which are essential to the outcome but [which] lie outside the control" of those who may be held liable — on "moral luck" as Williams defines it. ${ }^{3}$ Nagel drives this point home with an example of a "truck driver who accidentally runs over a child" — an example he borrows and adapts from Williams:

\begin{abstract}
The driver, if he is entirely without fault, will feel terrible about his role in the event, but will not have to reproach himself. . . However, if the driver was guilty of even a minor degree of negligence - failing to have his brakes checked recently, for example - then if that negligence contributes to the death of the child, he will not merely feel terrible. He will blame himself for the death. And what makes this an example of moral luck is that he would have to blame himself only slightly for the negligence itself if no situation arose which required him to brake suddenly and violently to avoid hitting a child. Yet the negligence is the same in both cases, and the driver has no control over whether a child will run into his path. ${ }^{4}$
\end{abstract}

As this example makes plain, luck is endemic to negligence liability. Liability in tort normally requires harm done and - when risk of injury is at issue - whether harm flows from careless conduct is normally a matter of luck quite beyond the control of the careless party. Jeremy Waldron begins a

\footnotetext{
${ }_{1}$ An earlier version of this paper was prepared for the conference on The Morality of Fortune held at the USC Department of Philosophy on March 24-25, 2006 under the auspices of the Center for Law and Philosophy. I am grateful to the participants in the conference for their comments and reactions, to Martin Stone for commenting on the paper. I also owe particular thanks to Scott Altman, Ben Zipursky and John Goldberg for valuable discussion and comments.
}

2Bernard Williams, "Moral Luck," Proceedings of the Aristotelian Society, supplementary vol. I. (1976), 115-35, reprinted in Bernard Williams' "Moral Luck," 20-39 (1981). Thomas Nagel's "Moral Luck" originally appeared in the same volume of the Proceedings of the Aristotelian Society as a reply to Williams' paper. Nagel revised it for inclusion in Thomas Nagel, "Mortal Questions," 24-38 (1979). I shall cite to the 1981 printing of Williams' paper and to the revised 1979 version of Nagel's paper.

${ }^{3}$ Williams, supra note, at 30.

4Nagel, supra note, at 28-29. 
JOURNAL OF ETHICS \& SOCIAL PHILOSOPHY $\mid$ VOL. 2, No. 1

STRICT LIABILITY AND THE MITIGATION OF MORAL LUCK

Gregory C. Keating

paper entitled Moments of Carelessness and Massive Loss,, 5 with the following story:

Two drivers, named Fate and Fortune, were on a city street one morning in their automobiles. Both were driving at or near the speed limit, Fortune a little ahead of Fate. As they passed through a shopping district, each took his eyes off the road, turning his head for a moment to look at the bargains advertised in a storefront window. (The last day of a sale was proclaimed, with 25 percent off the price of a pair of men's shoes.) In Fortune's case, this momentary distraction passed without event. The road was straight, the traffic in front of him was proceeding smoothly, and after a few seconds he returned his eyes to his driving and completed his journey without incident. Fate, however, was not so fortunate. Distracted by the bargain advertised in the shoe store, he failed to notice that the traffic ahead of him had slowed down. His car ploughed into a motorcycle ridden by a Mr. Hurt. Hurt was flung from the motorcycle and gravely injured. His back was broken so badly that he would spend the rest of his life in a wheelchair. Fate stopped immediately of course to summon help, and when the police arrived he readily admitted that he had been driving carelessly.

When Hurt recovered consciousness in [the] hospital, the first thing he did was instruct his lawyers to sue Fate for negligence. Considering the extent of his injury, the sum he sought was quite modest - $\$ 5$ million. . . But modest or not, it was sufficient to bankrupt Mr. Fate. . . 6

The general problem of moral luck - that responsibility is profoundly affected by factors beyond the control of the person held responsible - has two distinct dimensions in the case of accidental injury (and no doubt in many other cases). One dimension is concerned with attribution of moral blame: "If one negligently leaves the bath running with the baby in it, one will realize, as one bounds up the stairs toward the bathroom, that if the baby has drowned one has done something awful, whereas, if it has not, one has merely been careless." 7 How badly one has behaved and hence how much one should be blamed turns on consequences beyond one's control - on luck. The other dimension concerns the existence and extent of one's responsibil-

5 Jeremy Waldron, Moments of Carelessness and Massive Loss, in Philosophical Foundations of Tort Law 387 (David G. Owen, ed., 1995). While this is an artificial example, it illustrates a very real phenomenon. A 1970 U.S. Department of Transportation study reported: "In Washington, D.C., a 'good' driver viz. One without an accident within the preceding five years, commits on average, in five minutes of driving, at least nine errors of different kinds." U.S. Department of Transportation: Automobile Insurance and Compensation Study 1970, pp. 177-8, quoted in Tony Honore, Responsibility and Fault, 36-7 (1999).

6Id.

${ }^{7}$ Nagel, supra note, at 31. 
JOURNAL OF ETHICS \& SOCIAL PHILOSOPHY $\mid$ VOL. 2, NO. 1

STRICT LIABILITY AND THE MITIGATION OF MORAL LUCK

Gregory C. Keating

ity for having done harm, one's obligation to someone harmed to make amends for or repair the harm done. Fortune has no such obligation and Fate has a financially ruinous obligation, even though their actions were equally careless.

In contrast to one another, the first of these dimensions seems distinctively more moral and the second distinctively more legal. The extent of the agent's culpability, the degree to which he or she should be blamed, strikes us as predominantly a matter of moral assessment. We are appraising a person, determining what sort of mark should be entered on the ledger of his life and character. The existence and extent of obligations of reparation, by contrast, strikes us as predominantly a matter of legal liability. We are settling the responsibility of an injurer to her victim. But it would be an error to draw too sharp a distinction between the moral and the legal. A legal judgment of negligence expresses criticism and disapproval of the conduct involved, and it is a mistake to purge that legal criticism of any moral dimension. So, too, the legal obligation to repair harm wrongly inflicted imposed by the tort law of negligence overlaps with a perceived moral obligation of the same kind, and is no doubt at least partially rooted in and justified by that perceived moral obligation. Because the moral and the legal interpenetrate in these ways, our judgments about the role that moral luck should play in on our assessments of the moral culpability of persons cannot be wholly divorced from our judgments about the role that moral luck should play in our assessment of the legal liability of persons.

It is significant, then, that Thomas Nagel condemns strict liability as an "irrational ... moral position" in contradistinction to negligence liability, which takes a defensible position on moral luck. Negligence liability is morally defensible because it holds people "responsible for the contributions of fate as well as for their own - provided they have made some contribution to begin with." 8 The comparative irrationality of strict liability, however, cannot turn on the fact that it holds people accountable solely for fate. It doesn't. Holding "the contributions of fate" constant for the moment, strict liability holds people accountable for harms attributable to their agency whereas negligence liability holds people accountable for harms attributable to their culpable agency. If strict liability is morally irrational, it must be because it is irrational to hold people accountable for the consequences of their agency, as opposed to for the consequences of their faulty agency. Perhaps there is some reason why this is the case, though I am inclined to doubt it. ${ }^{9}$ But if there is some such reason, it is

8Nagel, supra note, at 31.

9Some unease with strict liability arises from contemplating it as a form of criminal punishment and condemnation, not tort liability. See e.g., Thomas M. Scanlon, What We Owe to Each Other, 266-67 (1998) (noting that attaching "legal penalty . . . to selling contaminated milk" even in the absence of fault may be permissible "[b]ut this enlargement of [punishment] to include morally unobjectionable activities . . . makes such laws more difficult to justify.") For reasons that should become clear, the form of strict tort liability that I am con- 
JOURNAL OF ETHICS \& SOCIAL PHILOSOPHY | VOL. 2, NO. 1

STRICT LIABILITY AND THE MITIGATION OF MORAL LUCK

Gregory C. Keating

not rooted in moral luck. On the contrary, one of the distinctive virtues of strict liability is that it is capable — in the social world in which we live - of mitigating the effects of moral luck. And it seems that there is a larger lesson lurking here: In tort, moving from highly individual to more collective conceptions of responsibility is one way of diminishing both the practical significance of, and the moral dissonance created by, "moral luck." Or so I shall suggest.

My argument begins by sketching an argument that strict liability in its modern form (usually known as "enterprise liability") is more fair than negligence liability. This detour will prove long but it is, I think, necessary. The (or even a) principal point of the law of torts cannot be to mitigate moral luck. The point of the law of torts is to protect us against various forms of harm and various violations of our rights. In the case of the tort law of accidents, the point is to protect us against physical harm. Beyond that, the law of torts must protect us against physical harm on terms that leave sufficient scope for us to pursue our other ends and which articulate appropriate relations among us as free and equal democratic citizens. Put differently, tort accident law protects - and struggles to reconcile - two preconditions of rational agency, namely, liberty (or freedom of action) and security (in the form of the physical integrity of the person). The mitigation of moral luck matters only insofar as the exacerbation or muting of moral luck by the design of the institutions of accident law can itself work a kind of harm, by exposing us unnecessarily to crushing blows at the hands of fate.

The argument therefore begins by setting out a fairness framework for appraising the choice between negligence and strict liability. It then proceeds to make an argument for the greater fairness of strict liability. This argument rests importantly on an understanding of the social world within which accidents arise. In our world, accidents characteristically arise out of organized activities, not out of discrete acts. A fundamental part of what makes enterprise liability more fair than negligence liability — and more protective both of our freedom of action and of our security — is that enterprise liability mitigates the effects of "moral luck" by attributing accidents to the activities which are pervasively responsible for them rather than to individual actors who happen to occasion them. Last, I suggest that there may be a larger lesson here concerning the attractions of comparatively collective conceptions of responsibility, in contradistinction to comparatively individual ones. Negligence liability exacerbates the role of luck because it attributes accidents which are the inevitable consequences of large, collectively conducted activities to the individual persons whose acts occasion those accidents in an es-

cerned to defend in this paper does not resemble the criminal strict liability that Scanlon has in mind. Strict enterprise liability in tort protects people against unavoidable and harsh penalties. 
JOURNAL OF ETHICS \& SOCIAL PHILOSOPHY | VOL. 2, NO. 1

STRICT LIABILITY AND THE MITIGATION OF MORAL LUCK

sentially random way. Strict enterprise liability diminishes the role of moral luck because it attributes accidents more collectively — because it charges accidents to activities not to individuals.

\section{A Fairness Framework}

\section{A. The Contours of Fairness}

The fairness conception that I shall sketch has a number of elements. One of these is a conception of persons. It supposes that we are each equal, independent persons, self-governing agents with purposes to pursue and lives to lead. We each have the capacity to lead our lives in accordance with some conception of their point, and a deep interest in living under institutions that enable us to do so. To make our lives answer to our aspirations for them, we need a substantial measure of security — of freedom from accidental injury and death at the hands of others. Our need for security, however, is only half the story. We also need a substantial measure of liberty - of freedom to put others at risk of physical harm in pursuit of our own ends - if we are to pursue projects and make our lives answer to our aspirations for them. When we act, we put others at peril, even if only very slightly and even when we act with appropriate caution. If we cannot put others at peril - cannot endanger their security - we cannot act and so cannot pursue our ends and lead our lives. Maximal security extinguishes liberty and maximal liberty extinguishes security. Yet substantial measures of both liberty and security are essential if we are to have the chance to make our lives answer to our aspirations for them. This is the dilemma at the heart of accident law.

When the law of accidents licenses the imposition of a risk, it enhances the freedom of some and imperils the security of others. Those who impose the risk are set free to pursue ends and activities that they value, and their pursuit exposes others to risks of physical harm. When the law of accidents forbids the imposition of some risk, it does the reverse - it curbs the freedom of prospective injurers and enhances the security of potential victims. Risk impositions thus pit the liberty of injurers against the security of victims and the law of accidents sets the terms on which these competing freedoms are reconciled. The task of the tort law of accidents is to reconcile liberty and security on terms that are both favorable and fair. Favorable terms enable people to pursue their aims and aspirations over the course of complete lives; fair terms reconcile the competing claims of liberty and security in ways that even those they burden cannot reasonably reject.

The question of how best to reconcile the pursuit of activities we value with the physical and psychological integrity that those activities can jeopardize is, of course, an issue that each of us must face individually. What ends are worth the risks they entail? Are the risks of death and disfigurement that are the price of scaling Mount Everest worth the sense of accomplishment 
JOURNAL OF ETHICS \& SOCIAL PHILOSOPHY | VOL. 2, NO. 1

STRICT LIABILITY AND THE MITIGATION OF MORAL LUCK

Gregory C. Keating

that comes from standing on its summit? Are increased risks of cancer worth bearing as the price of performing groundbreaking medical research? Are increased risks of cancer worth bearing as the price of earning a living? This kind of individual choice is not, however, the chief concern of the law of accidents. The problem of accidental harm is a problem of how best to reconcile the competing claims of liberty and security for a plurality of persons.

More fully, the problem of accidental harm requires reconciling the competing claims of liberty and security for a plurality of persons, each of whom is free, all of whom are equal, and among whom diverse and incommensurable conceptions of the good flourish. Because people are equal and independent, the terms of accidental risk imposition must be ones that equal people might freely accept as legitimate for the governance of their lives in common. Diverse and incommensurable ends and aspirations flourish among free and equal people because the range of valuable activities and valuable ways of life is diverse. We value different things in life, and hold different hopes for our lives. Because people have distinct lives to lead, and because their aims and ends diverge, the principles of social choice differ markedly from the principles of individual choice. Individually, it may be rational to expose ourselves to risks that it would be unreasonable — unfair - to impose on others.

\section{Rationality and Reasonableness}

The distinction between reasonableness and rationality is one drawn by ordinary discourse. ${ }^{10}$ Rationality requires the intelligent pursuit of one's ends, whatever those ends are. Reasonableness requires taking the impact of one's conduct on other people into account as a circumstance capable of influencing one's decisions, and being prepared to govern one's conduct on a basis acceptable to others whom one's conduct affects. Rationality and reasonableness may well diverge. It may be perfectly rational for a party in possession of a dock to demand exorbitant compensation for permitting a ship to tie up at the dock during a gale.11 It may be equally rational for the ship owner to pay such compensation; after all, the alternative is a very high likelihood that the ship will be completely destroyed. But it is also unreasonable for the dock owner to insist on such exorbitant compensation. The principle expressed in the dock owner's demand — "You, ship owner, should pay me a penny less than the loss you stand to suffer if I refuse you permission to

${ }_{10}$ See W.M. Sibley, The Rational Versus the Reasonable, 62 Philosophical Review 554 (1953). Sibley's description of rationality, which the text follows, is a basic and familiar one, but probably not the only way of specifying the concept, even at a very general level.

${ }^{11}$ The circumstance (though not, so far as I know, the bargaining) arose in Vincent $v$. Lake Erie Transportation Co., 124 N.W. 221 (Minn. 1910). 
JOURNAL OF ETHICS \& SOCIAL PHILOSOPHY | VOL. 2, NO. 1

STRICT LIABILITY AND THE MITIGATION OF MORAL LUCK

dock" - is not an acceptable basis for unforced cooperation among ship owners and dock owners. This sort of hard bargaining is rational, but unreasonable, because it does not count the property interest of the ship owner as equal in importance to the dock owner's own property interest.

Drawing on this ordinary distinction between rationality and reasonableness, it makes sense to say that risk impositions may be at once rational and unreasonable. We may say, for example, that the rationality of exposing oneself to a risk depends on the end furthered by the exposure, the importance that one attaches to furthering that end, and the efficacy with which the exposure will further the end. The canons of rationality thus give wide rein to individual subjectivity, and are naturally expressed in the language of efficiency. Individuals are free to value the burdens and benefits of risks by any metric they choose, and it is surely natural for them to value burdens and benefits by their own subjective criteria of well-being. It is also rational for individuals to run risks whenever — by their own lights — the expected benefits of so doing exceed the expected costs, and to decline to run risks whenever the expected costs exceed the benefits.

The rationality of a risk imposition is not, however, enough to guarantee its reasonableness. It is not necessarily reasonable for people to expose others to risks because - by the potential injurer's own evaluation of the end furthered by the risk imposition — the benefits of imposing the risk exceed the burdens of having to bear exposure to it. Rational risk impositions are not necessarily reasonable ones because other people have different values and distinct lives. Because some people will die at the hands of risk impositions whose benefits accrue to others, the separate lives of different people cannot be collapsed into a single life that reaps both the burdens and the benefits of rational risk impositions. The diversity of values compounds the problem: In a world of distinct persons who affirm diverse and incommensurable conceptions of the good, there is no reason to assume that those who are put at risk value the ends pursued through the relevant risk impositions in the way that those imposing the risks do. The fact that you may be prepared to run enormous risks for the advancement of medical knowledge does not mean that I am prepared to do so. The diverse aims of a plurality of persons cannot be converted into a single scale, so that we may make collectively the same kinds of judgments that we each make individually. Because lives are distinct and values diverse, there is a fundamental difference between putting oneself at risk in pursuit of one's own purposes and putting someone else at risk for that very same purpose. 
JOURNAL OF ETHICS \& SOCIAL PHILOSOPHY | VOL. 2, NO. 1

STRICT LIABILITY AND THE MITIGATION OF MORAL LUCK

Gregory C. Keating

\section{Reasonableness Refined}

Contractualist moral and political philosophy ${ }^{12}$ elaborates on the general idea of reasonableness in a number of ways. First, it supposes that reasonableness and rationality are (in a certain form) complementary notions. Reasonable people have diverse ends: diverse conceptions of their own rational advantage, of what it is that they intend to realize in cooperation with others. Second, contractualism supposes that reasonable people share the common aim of reaching unforced agreement on fair terms of cooperation: terms that are fair for people who are both independent and equal, and who have diverse conceptions of their own rational advantage.

The interactions of reasonable people are thus different from the interactions of purely rational actors. Rational egoists interacting with other rational egoists seek to determine the course of action which will best advance their own interests, given the existence of other rational agents seeking to advance their own interests as best they can. Purely rational agents are led to cooperate on terms that are mutually advantageous - on terms that make everyone better off with respect to their pre-existing situation, in the way that Pareto-superior transactions do. Reasonable people, by contrast, do not interact with other reasonable people by seeking their own greatest advantage. Reasonable people seek to cooperate on fair terms with other - equal, independent and reasonable - people.

Fair terms do not necessarily advantage everyone they affect in the sense of making everyone they affect better off than they were under the preexisting distribution of advantages. Measured against the baseline of preexisting entitlements, the move from an unfair (or unjust) situation to a more fair (or more just) one does not improve the situation of those who benefited from the unfairness or injustice which is rectified. For example, the enfranchisement of some previously disenfranchised group on the ground that members of that group are equal persons entitled to the political and civil rights accorded equal citizens, does not improve the lot of those who benefited previously from the subordination and disenfranchisement of the group. Reasonableness is thus linked to an idea of mutual benefit, but not to the idea of mutual advantage against a pre-existing baseline of entitlements. Reasonableness is linked to reciprocity - to terms that define appropriate terms of cooperation among equals.

Among equals, fair terms of cooperation are determined not by comparing advantage and disadvantage against the baseline of pre-existing entitlements but by comparing burdens and benefits to those affected under alter-

${ }^{12}$ I am drawing here principally on the discussions of reasonableness in John Rawls, Political Liberalism 48-54 (rev. ed. 1996), and Scanlon, What We Owe to Each Other, supra note 9 at 19197 (1998). 
JOURNAL OF ETHICS \& SOCIAL PHILOSOPHY | VOL. 2, NO. 1

STRICT LIABILITY AND THE MITIGATION OF MORAL LUCK

Gregory C. Keating

native possible principles of cooperation. The reasonableness of preferring a regime of strict liability to one of negligence, for example, depends on comparing burdens to victims under negligence to burdens to injurers under strict liability - not on comparing the advantages to some and disadvantages to others of moving from a regime of negligence to one of strict liability. On its face, negligence places greater burdens on victims than strict liability does because negligence liability leaves the costs of non-negligent accidents on the victims of those accidents, whereas strict liability shifts the costs of those accidents onto injurers. On its face, then, strict liability places greater burdens on injurers than it does on victims. Prima facie, it is reasonable to ask injurers to bear the greater burdens that strict liability imposes on them only if those greater burdens are less than the greater burdens that negligence liability places on victims.

\section{Interpersonal Comparison}

Because the reasonableness of possible terms of cooperation turns on their distribution of the burdens and benefits of cooperation, some criteria for comparing burdens and benefits are necessary. When people affirm diverse and incommensurable ends, acceptable criteria of interpersonal comparison must be "mutually acceptable to people whose preferences diverge." ${ }_{13}$ The overlap in people's needs (in contrast to the divergence in their aspirations, preferences and wants) makes mutual acceptability possible. People whose preferences diverge may well still need many of the same things: liberty, security, health, income and wealth, for example. The ambition behind Rawls" specification of "primary goods" is to identify the institutional conditions (equal basic liberties) and "all purpose goods" (wealth and income) essential to the pursuit of a wide variety of aims and aspirations. The aim is to identify the goods that people need to pursue their final ends and more transient preferences, and to base interpersonal comparisons on these goods. ${ }^{14}$

${ }^{13}$ T.M. Scanlon, Preference and Urgency, 72 J. Phil. 655, 668 (1975) [henceforth cited as Scanlon, Preference and Urgency].

14John Rawls, Political Liberalism 178-90 (rev. ed. 1996). In the parlance of the interpersonal comparison literature, these are generally described as "objective" criteria of interpersonal comparison, in contradistinction to "subjective" ones. "Subjective" criteria of interpersonal comparison evaluate "the level of well-being enjoyed by a person in given material circumstances or the importance for that person of a given benefit or sacrifice . . . solely from the point of that person's tastes and interests." Scanlon, Preference and Urgency, 656. Objective criteria appraise burdens and benefits in terms that are "the best available standard of justification . . . mutually acceptable to persons whose [aims, ends and] preferences diverge." Id. at 668. 
JOURNAL OF ETHICS \& SOCIAL PHILOSOPHY | VOL. 2, NO. 1

STRICT LIABILITY AND THE MITIGATION OF MORAL LUCK

Gregory C. Keating

Freedom of action and security are preconditions of effective moral agency. They are, therefore, conditions on whose importance people with diverging ideals and preferences can agree. Their importance does not depend on affirming any particular preferences, on holding any particular set of ends and aspirations. Their importance depends on having ends and aspirations, and on having a fundamental interest in being able to realize those ends and aspirations over the course of a normal life span. Freedom and security are essential conditions for the pursuit of most of the ends human beings do hold, especially when we think of pursuing ends over the course of a lifetime. Risks of physical harm materialize into physical harm, and even when physical harm does not end in premature death, it can profoundly disrupt the pursuit of people's aims and aspirations. Serious physical injury can render the realization of some ends impossible and severely impede the pursuit of others. Conversely, freedom of action is prima facie enabling of the pursuit of one's ends, whatever they are. Being forbidden to act at all - because the risk of physical injury to others is too great - would cripple the pursuit of almost any end. Being forbidden to act in certain ways - because those ways endanger other people too much — tends to impede the pursuit of at least some ends.

The reasonableness of risk impositions thus turns on the way that they reconcile the competing claims of liberty and security. Risk impositions are reasonable when the freedom to impose a risk is more valuable than the foregone security that is the price of that risk imposition. They are unreasonable when the security lost is more valuable than the freedom of action gained. More concrete categories are necessary when we make the judgments about the reasonableness of particular risks and precautions, as we do in negligence law, for example.15 The question before us, however, is different. We are concerned with the reasonableness of choosing negligence over strict liability, and vice versa. In this context, the relatively abstract account of the interests at stake given by the terms "liberty" and "security" seems sufficient. The choice between negligence and strict liability is a highly general one, and it is natural to think about it in highly general terms. Getting a grip on this question requires not that we make the categories of liberty and security more concrete, but that we characterize these two competing forms of liability for accidental injury.

Before we turn to this task, however, it is worth noting that the framework sketched here departs from much (though not all) recent philosophical writing on the law of torts, because it does not place corrective justice at the

${ }^{15}$ For discussion of how the common law of negligence proceeds in this regard, see Gregory C. Keating, Reasonableness and Rationality in Negligence Theory, 48 Stan. L. Rev. 311 (1996); Charles Fried, An Anatomy of Values, 191-93 (1970). 
JOURNAL OF ETHICS \& SOCIAL PhiLOSOPHY $\mid$ VOL. 2, NO. 1

STRICT LIABILITY AND THE MITIGATION OF MORAL LUCK

Gregory C. Keating

center of its understanding of tort law. ${ }^{16}$ Placing corrective justice at the center of tort law, however, puts the cart before the horse. "Reasons of corrective justice are reasons for or against restoring people's relative positions to what they were before, or would have been apart from, some action or series of actions." ${ }_{17}$ The identification of those actions which require correction takes precedence over their correction, and that prior task is more fundamental to the law of torts. "The principle that the plaintiff is entitled to be made whole," as Ben Zipursky has observed, "lies at the level of remedies, applicable once a right of action is already recognized." 18 The primary role of the law of torts - and of the law of accidents more generally — is not to correct but to protect. ${ }^{19}$ The primary role of the law of torts is to reconcile the competing claims of liberty and our security in a way which secures favorable conditions for the exercise of our rational agency.

There is, then, a world of difference between a conception of tort law constructed around the idea of corrective justice and a conception constructed around the concept of mutual justifiability. The idea of mutual justifiability invokes the legacy of the social contract tradition and asks what regime of rights and obligations those affected by risks of injury and their reduction might reasonably agree to. ${ }^{20}$ At the center of this approach is an un-

${ }^{16}$ Important instances of recent philosophical writing on the law of torts which do place corrective justice at its (and their) center include Alan Brudner, The Unity of the Common Law (1995); Jules Coleman, The Practice of Principle (2001); Jules Coleman, Risks and Wrongs (1992); Arthur Ripstein, Equality, Responsibility and Luck (1999); Ernest Weinrib, The Idea of Private Law (1995); and Martin Stone, On the Idea of Private Law, 9 Can. J.L. \& Jurisprudence 235 (1996). These varying accounts share the idea that the idea corrective justice is, as Coleman puts it, the "overarching ambition or purpose" of tort law. (Risks and Wrongs, 395)

17John Gardner, Discrimination as Injustice, 16 Oxford Journal of Legal Studies, 353, 357 (1996).

18Benjamin C. Zipursky, Civil Recourse, Not Corrective Justice, 91 Geo L. J. 695, 749 (2003).

${ }^{19} \mathrm{On}$ the contrast between correction and protection and the priority of protection, see Hanoch Sheinman, Tort Law and Corrective Justice, 22 Law and Philosophy 21, 41-47, 67-73 (2003).

${ }^{20}$ Because it gives mutual justification priority over mutual protection, this position falls on the Kantian side of the divide between Kantian and Humean (or Millian) theories of political morality. A justified tort regime is one that everyone governed by its terms could reasonably accept. But the idea of reasonable acceptability itself incorporates mutual protection of vital interests: A tort regime that everyone affected by it might reasonably accept is one which protects everyone's interests in liberty and security on fair terms. For this general conception, see Scanlon, What We Owe to Each Other, supra note, at 268-72. Scanlon argues that reasonable rejectibility understood in contradistinction to reasonable acceptability should be placed at the center of a reasonableness-based view. Essentially, he argues that the idea of reasonable rejectability is decisive because what people might reasonably reject sets the boundaries of reasonable cooperation. He may well be right but, for purposes of this paper, we need not take a stand on the distinction. 
JOURNAL OF ETHICS \& SOCIAL PHILOSOPHY $\mid$ VOL. 2, No. 1

STRICT LIABILITY AND THE MITIGATION OF MORAL LUCK

Gregory C. Keating

derstanding of tort law which gives precedence to the protection of competing interests in liberty and security on fair terms, thus giving both protection and "risk-distributive justice" priority over corrective justice. ${ }^{21}$ Risks of physical injury involve both burdens (principally precaution costs and injuries) and benefits (the gains won by imposing risks). The law of accidents determines the terms on which risks may be imposed and so distributes the burdens and benefits of risk imposition. The corrective justice conception of tort, by contrast, either assumes a prior account of the wrongs that tort law rectifies or mistakes secondary duties of reparation for the primary norms of tort law.

\section{B. Fairness and the Choice Between Negligence and Strict Liability}

The tort law of accidents is now, and long has been, divided between realms of negligence and realms of strict liability. The choice between these rival principles of responsibility for harm done is, arguably, the most fundamental choice in the tort law of accidents. Particular conceptions of liability - such as the enterprise liability conception of strict liability — articulate these regimes in specific ways. But a general characterization of the difference between them can still be given. The essential distinction between the two forms of liability (on my view ${ }^{22}$ ) is that negligence liability criticizes conduct, whereas strict liability criticizes merely the failure to make reparation for harm done. The imposition of negligence liability on a defendant condemns the defendant's conduct as wrongful. Negligent conduct is unreasonable conduct, insufficiently careful conduct.

${ }^{21}$ Tony Honore, Responsibility and Fault, supra note, at 9, 78-82, 86, 90-91 explicates the idea of "risk-distributive justice." As Honore shows, a conception of tort built around "riskdistributive justice" makes room for corrective justice as a dependent aspect of the law of torts - dependent because the rectification of injustices is subordinate to the specification of the just terms whose violation triggers an obligation of repair.

${ }^{22}$ Although the division of the law of accidents between realms of negligence and realms of strict liability is a longstanding one, how best to understand the difference between these competing principles of responsibility remains a contested matter among tort scholars. There are, for example, scholars who see strict liability as essentially a surrogate kind of negligence liability, and scholars who see it as a distinct and competitive form of liability. Richard Posner may be the pre-eminent example of the first view. See Richard A. Posner, $A$ Theory of Negligence, 1 J. Legal Stud. 29, 42-44 (1972). Ripstein, supra note, at 70-72 (1999) ("Courts addressing [certain recurring situations subject to strict liability] can be thought of as adopting conclusive presumptions of negligence when injuries ensue from such actions.") Guido Calabresi and Robert Keeton are among those who see it as a distinct and competitive kind of liability. See Guido Calabresi, The Costs of Accidents: A Legal and Economic Analysis, 68-134 (1970); Robert Keeton, Conditional Fault in the Law of Torts, 72 Harv. L. Rev. 401 (1959). The best characterization of the distinction between the two forms of liability may well depend in part on what the best justification for the two forms of liability is. The characterization offered here should therefore be viewed as a contestable one. 
JOURNAL OF ETHICS \& SOCIAL PHILOSOPHY $\mid$ VOL. 2, NO. 1

STRICT LIABILITY AND THE MITIGATION OF MORAL LUCK

Gregory C. Keating

Strict liability, by contrast, does not condemn the conduct responsible for the infliction of injury. It condemns - calls unreasonable — only the failure to compensate for the infliction of injury. The injury-inflicting conduct subject to strict liability is not itself wrong. It is tortious only when injury is inflicted and reparation is not made for the harm thereby done. The wrong is harming without repairing. Negligence liability is liability for wrongful conduct; strict liability is liability for conduct which is wrongful only because (and only when) reparation for harm done is not made promptly and voluntarily. Put differently, the fundamental difference between strict and negligence liability is that, under strict liability, the payment of damages to those injured by the characteristic risks of an activity is a condition for the rightful conduct of an activity, ${ }^{23}$ whereas, under negligence liability, the payment of damages is a matter of redress for wrongful conduct - for the wrongful infringement of the property and physical integrity of others.

The choice between negligence and strict liability is thus a choice both between leaving non-negligent accident costs — costs arising out of risks reasonably imposed — on the victims who suffer them and shifting such losses back to the injurers who inflict them, and between reasons for imposing liability. Negligence is liability for unreasonable risk imposition; strict liability is liability for reasonable risk imposition. The reasonableness of preferring negligence to strict liability (and vice versa) depends initially on comparing burdens and benefits under these competing principles. Prima facie, negligence places greater burdens on victims because negligence requires victims to shoulder the costs of non-negligent accidents, whereas strict liability places prima facie greater burdens on injurers, because strict liability requires injurers to shoulder the costs of non-negligent accidents. Initially, we are asking when it is reasonable to place greater burdens on victims and when it is reasonable to place greater burdens on injurers.

\section{Benchmarks of Fairness}

Judgments regarding the fair distribution of the costs of non-negligent accidents do not arise in a vacuum, because accidents themselves do not arise in a vacuum. Accidents arise, for the most part, out of mutually beneficial

\footnotetext{
${ }^{23}$ Legal doctrine and rhetoric often come very close to putting the matter this way. For example, Koos v. Roth, 652 P.2d 1255, 1262 (Or., 1982), a leading case on abnormally dangerous activity liability, explains that, under strict liability, "the question is not whether the activity threatens such harm that it should not be continued. The question is who shall pay for harm that has been done." The Comment on Clause (c) to \520 Abnormally Dangerous Activities of the Restatement of Torts, Second (1977) observes that "the utility of [the injurer's] conduct may be such that he is socially justified in proceeding with his activity, but the unavoidable risk of harm that is inherent in it requires that it be carried on at his peril, rather than at the expense of the person who suffers harm as a result of it."
} 
JOURNAL OF ETHICS \& SOCIAL PHILOSOPHY | VOL. 2, NO. 1

STRICT LIABILITY AND THE MITIGATION OF MORAL LUCK

activities carried out by legal equals. Cooperative practices among equal persons give rise to natural focal points, or benchmarks, of fair division. ${ }^{24}$ To see this, consider the case for the difference principle in its simplest form.

In its simplest form, the case for the difference principle depends on: (1) the general idea of society as a cooperative venture among equal persons; and (2) on particular features of the basic structure of society, namely, the pervasive effects that the basic structure of society has on the life prospects of those who live under its institutions. ${ }^{25}$ Prima facie, equal participants in a system of social cooperation should share equally in the system's benefits (and burdens). Reasonable people, participating as equals in a practice which creates both burdens and benefits, would take equal division as the presumptively fair benchmark - the focal point - from which their deliberations about the apportionment of burdens and benefits of social cooperation should start. ${ }^{26}$ The "priority of those worst off" which characterizes the difference principle - the fact that the distribution of income and wealth has to be justified especially to them - arises against this benchmark. The claims of those worst off under institutions which permit economic inequalities take on a certain priority, both because those worst off are receiving less than equal shares of the benefits to which they have a prima facie equal claim, and because principles governing permissible inequalities of wealth and income with respect to the basic structure of society have a pervasive and profound effect on the life prospects of those subject to them.

Risks of physical injury likewise arise in the course of social cooperation among equal persons. Equality of division is likewise the presumptively fair benchmark when the burdens and benefits of those practices affect those touched by them equally. But practices of risk imposition rarely affect every member of society equally. Risk of physical injury is pervasive in a technologically advanced society, but the activities which give rise to it are diverse and often quite particular. The injuries that preoccupy accident law arise from a variety of sources — from driving and flying, from milling, mining and manufacturing, from producing and consuming pharmaceuticals, from playing sports and playing with toys. These activities rarely affect every member of society in equal ways. They tend to benefit some more directly

${ }^{24}$ Rawls introduces the idea of a "natural focal point" in explaining why the difference principle expresses a principle of reciprocity. John Rawls, Justice As Fairness: A Restatement, 123 (2001) [henceforth cited as Rawls, Restatement]. He takes the idea from Thomas Schelling, The Strategy of Conflict (1960).

${ }^{25}$ See T.M. Scanlon, Contractualism and Utilitarianism in The Difficulty of Tolerance, 124, 149-50 (2003); Rawls, Restatement, 10-12, 52-57, 97-101 (2001).

${ }^{26}$ Rawls, Restatement, 124 (“. . . the difference principle expresses the idea that, starting from equal division ....") 
JOURNAL OF ETHICS \& SOCIAL PHILOSOPHY | VOL. 2, NO. 1

STRICT LIABILITY AND THE MITIGATION OF MORAL LUCK

than they benefit others, and to burden some more directly than they burden others.

The fact that most activities responsible for risks of physical injury burden and benefit people differentially both sets the subject matter of accident law apart from the basic structure of society that is the concern of Rawls' theory of justice, and affects the presumptively fair benchmark from which reasonable people would begin deliberating about the distribution of accident costs. The basic structure of a society has a pervasive and profound effect on the life prospects of every member of society. Practices of risk imposition generally do not. This differential distribution of burdens and benefits affects the natural focal point from which deliberation about fair division begins. When the benefits of a practice are differentially distributed, the presumptively fair way for equals to distribute the burdens of that practice is in proportion to those (differentially distributed) benefits. Those who benefit from the imposition of risks should bear the costs of the accidents which result from those risks.

\section{Risk Impositions Within and Between Communities}

Because benefit and burden should presumptively be proportional, it is useful to distinguish two fundamental kinds of cases where practices of risk imposition distribute burden and benefit differently. In the first kind of case, risk impositions occur within "communities of risk." In the second, risk impositions take place between communities.

A "community of risk" is present in its strongest form when potential injurers are also potential victims, and equally so. (In tort law, the risks of the road are often taken to be a rough approximation of a perfect community of risk.) Each member of the community then has her security compromised by having to bear risks imposed by others, but each also has her liberty enhanced by being able to impose risk on others. Within a community of risk, risks may be fairly imposed and mutually beneficial in a particularly strong way. When each member of a community is equally a potential injurer and a potential victim, risks will be fairly imposed: Each member of the community will be exposed to equal risks by each other member of the community, and will impose equivalent risks on each other member of the community. (In an idealized community of the highway, for instance, each driver will be equally at risk and equally putting others at risk.) If the risks imposed are reasonable ones - if the freedom to impose the risks is worth more than the foregone security that is their price — then each member of the community will also benefit from the right to impose those risks. (Each driver will gain more from the mundane freedom to take his or her car on the road, for example, than he or she loses from having to bear the risks created by the presence of other cars on the road.) Within a perfect community of risk, the burdens and benefits of accidental risk imposition are fairly distributed because they are 
JOURNAL OF ETHICS \& SOCIAL PhiLOSOPHY $\mid$ VOL. 2, No. 1

STRICT LIABILITY AND THE MITIGATION OF MORAL LUCK

equally distributed. In a community of equals, equal division is prima facie fair — prima facie reasonable.

Risks are imposed by members of one community on members of another community when potential injurers and potential victims engage in distinct activities which do not impose equivalent risks on one another. When potential injurers play cricket and potential victims walk through their yards, ${ }^{27}$ members of one community (cricket players) are imposing greater risks on members of the other community (homeowners or pedestrians) and bearing less in the way of exposure to risk. When one party mills and the other party mines, 28 because water is a resource for milling and a detriment to mining the milling party is imposing greater risk on the mining party and bearing less in the way of exposure to risk. Even if the risks that the cricket players and the millers impose are reasonable, the burdens and benefits of those reasonable risks are not fairly distributed.

Practices of risk imposition which are intermediate between these two poles are both easy to conjure up and common. For example, given the importance of driving to our daily lives (this from someone who lives in Los Angeles), we may all stand to benefit from the practice of transporting large quantities of gasoline over the roads in tanker trucks, even though this method of transport creates risks of massive explosion, and even though most of us never expect to make use of the legal right to transport gasoline in this manner. ${ }^{29}$ Residents of Manhattan, for example, generally gain nothing of value from the right to haul gasoline by tanker. Indeed, they may drive so infrequently that they gain far less than Angelenos do from this method of transporting gasoline. But even Manhattanites benefit indirectly from the enterprise of transporting gasoline by tanker trucks, even if they do not impose risks on gasoline tankers equivalent to the risks that gasoline tankers impose on them, and even if they benefit less than Angelenos. Their life prospects may be improved by virtue of the prosperity created and sustained by the practice of transporting gasoline by tractor trailer, and even Manhattanites may benefit through the use of private automobiles that the practice enables.

In all of these cases, the fairest - most reasonable - distribution of the costs of accidents is open to argument. But the antecedent distribution of burdens and benefits by a practice of risk imposition bears on deliberations of fairness in an important way. The antecedent distribution of burdens and benefits by a practice of risk imposition sets the benchmark or focal point

${ }^{27}$ Bolton v. Stone, 1951 A.C. 850 (appeal taken from C.A.).

${ }^{28}$ Fletcher v. Rylands, 159 Eng. Rep. 737 (Ex. 1866), affd 3 L.R.-E. \& I. App. 330 (H.L. 1868) (appeal taken from Ex.).

${ }^{29}$ The transport of gasoline in this manner precipitated the death of the victim in Siegler $v$. Kublman, 502 P.2d 1181, 1187 (Wash. 1972). 
JOURNAL OF ETHICS \& SOCIAL PHILOSOPHY | VOL. 2, NO. 1

STRICT LIABILITY AND THE MITIGATION OF MORAL LUCK

from which deliberations about fair distribution begin. It is presumptively reasonable - presumptively fair — for the burdens of a risky activity to be borne by those who benefit from it. Prima facie, burden and benefit should be proportional. Prima facie, losses should be shifted if their shifting would improve the distribution of burden and benefit. And this is (prima facie) true even if the risks which resulted in those losses were reasonably imposed.

Let us retrace our steps. Reasonableness requires (1) taking the impact of one's conduct on other people into account as a circumstance capable of influencing one's decisions, and (2) being prepared to govern one's conduct on a basis acceptable to others whom one's conduct affects. Reasonable people seek to cooperate on fair terms with other - equal, independent and reasonable - people. Fair terms enable each person to pursue his or her own aims and ends on terms that all those affected by them could accept. When risks of physical injury are at issue, the terms on which risks are permissibly imposed and accident costs distributed reconcile competing claims of liberty and security. Liberty and security enable people with diverse aims and ends to realize those ends, whatever they happen to be. A substantial measure of each is necessary for people to realize their particular plans and aspirations. The predicament of accident law is that, when risks of physical injury are at stake, liberty and security conflict and the task of accident law is to reconcile liberty and security on terms that are fair and therefore acceptable to those they affect.

Presumptively, fair terms of cooperation are equal terms. In a cooperative venture among equal persons, it is prima facie fair to distribute burdens and benefits equally. Equal persons should be entitled to impose equal risks on one another, and to share equally in the benefits and burdens of risk impositions. Deliberation about the fair terms of cooperation begins from this starting point. Deliberation about the fair distribution of accident costs, however, moves away from the benchmark of equal division, because practices of risk imposition generally benefit and burden those they affect differentially. When burden and benefit are distributed differentially by a practice of risk imposition, proportionality of benefit and burden — not equality of benefits and burden - is the natural focal point or benchmark from which deliberation over fairness begins. Prima facie, burdens should be shared in proportion to benefits. 
JOURNAL OF ETHICS \& SOCIAL PHILOSOPHY | VOL. 2, No. 1

STRICT LIABILITY AND THE MITIGATION OF MORAL LUCK

Gregory C. Keating

\section{The Fairness of Strict Enterprise Liability}

Within the modern law of torts, strict liability ideas find their fullest and most distinctive expression in the theory of enterprise liability. ${ }^{30}$ The theory of enterprise liability asserts: (1) that accident costs should be internalized by the activity responsible for them; and (2) that accident costs should be both dispersed - not concentrated - and distributed among the participants in the activity responsible for them. The various forms that enterprise liability takes - both within the common law of torts and in administrative alternatives to the common law — reflect different judgments of whether the pertinent activity is firm-wide (as with respondeat superior and workers' compensation); or industry-wide (as with black lung disease and nuclear power); or defined by an identifiable and salient activity (as with no-fault automobile insurance and vaccinations); or society wide (as with the New Zealand compensation scheme). ${ }^{31}$ Whereas negligence liability typically attributes accidents to faulty actions, enterprise liability typically attributes accidents to enterprises.

At first glance, the comparative fairness of negligence and strict liability turns on whether it is fairer to place the costs of accidents which should not have been prevented on those whose actions have occasioned them, or to

30Enterprise liability conceptions do sometimes surface within negligence law, though negligence liability thwarts their full realization. See Gregory C. Keating, The Theory of Enterprise Liability and Common Law Strict Liability, 54 V and. L. Rev. 1285, 1329-33 (2001).

${ }^{31}$ See Gregory C. Keating, Rawlsian Fairness and Regime Choice in Tort Theory, 72 Fordham L. Rev. 1857, 1861-62, 1890-1912 (2004) [henceforth cited as Rawlsian Fairness]. Compare Honore, Responsibility and Fault, supra note, at 90-91. For present purposes, the point is that the law constructs the enterprise, through the exercise of political and juridical judgment. The attribution of accidents to activities which is part of this construction requires the use of various tests designed to identify the "characteristic risks" of an activity (e.g., in the way that the "scope of employment" test in vicarious liability law seeks to identify the characteristic risks of a firm's activity). See Keating, Rawlsian Fairness, at 1861, 1900-01, 1909-12.

The evaluative nature of these tests bears underscoring. Because all accidents arise at the intersection of two or more activities, several first-rate tort theorists assert that "general strict liability" is conceptually impossible. The thought is that strict liability is liability for harm caused and harm is always caused by more than one activity. See e.g., Stephen Perry, The Impossibility of a General Strict Liability, 1 Can J.L \& Jurisprudence 147 (1989); Ripstein, supra note, at 32-53. Perry and Ripstein conclude, therefore, that we cannot attribute accidents to activities without employing fault criteria. This is a nonsequitur. Some nonfault rules for attributing accidents to activities — the "scope of the employment" test in the law of respondeat superior, the scope of the risk test for abnormally dangerous activities, the manufacturing defect test in product liability law, and the "in the course of employment" test in workers' compensation law — connect accidents and activities very effectively. These "nonfault attribution rules" are, however, evaluative: They express normative judgments about the character of an enterprise. The lesson here is that Perry and Ripstein are right to think that rules for attributing accidents to activities must be evaluative, but wrong to think that all evaluative judgments are judgments of fault. 
JOURNAL OF ETHICS \& SOCIAL PHILOSOPHY | VOL. 2, NO. 1

STRICT LIABILITY AND THE MITIGATION OF MORAL LUCK

Gregory C. Keating

leave those costs on the victims who have suffered the accidents. But the very statement of the idea of enterprise liability transforms the question. Enterprise liability embodies a particular idea of fairness, an idea centered on the distribution of the burdens and the benefits of risky activities. Enterprise liability expresses the idea that the burdens of accidental injury should be distributed across those who benefit from the risks which result in those injuries. This is a distinctively collective conception of responsibility and it is paired with a particular conception of the social world within which accidental injuries arise. That social world differs sharply from the social world presupposed by traditional fault liability and its more individualist understanding of responsibility.

\section{Two Social Worlds}

Writing in 1897, Oliver Wendell Holmes observed that "our law of torts comes from the old days of isolated, ungeneralized wrongs, assaults, slanders and the like..." whereas "the torts with which our courts are kept busy today are mainly the incidents of certain well-known businesses. . . . railroads, factories, and the like." 32 Implicit in Holmes' remark is a distinction not just between two kinds of accidents, but between two kinds of social worlds. Stylizing and simplifying, we can call these two worlds the "world of acts" and the "world of activities," respectively. The "world of acts" is Holmes" world of "isolated, ungeneralized wrongs." The "world of activities" is the world in which accidents are the "incidents" of organized enterprises.

In the "world of acts," risks are discrete. The typical actor is an individual or a small firm which creates risk so infrequently that harm is not likely to materialize from any single actor's conduct. The typical accident materializes out of the activity of isolated, unrelated actors, acting independently (i.e., natural persons or small firms separately engaging in activities on an occasional basis). Taken as a whole, the activities of these individual actors are diffuse and disorganized, and quite possibly actuarially small. The dogfight that precipitated Brown v. Kendall 3 is a representative tort in this world: It arose out of a chance encounter between unrelated parties, neither of whose activities were large enough to make such misfortunes commonplace and expected. In the "world of acts," then, risks are isolated, "one-shot" events. Harm, when it materializes, is a misfortune. Because actors are small, and

32O.W. Holmes, The Path of the Law, in Collected Legal Papers 167, 183 (1954 [original publication date], 1920). The paper itself was originally delivered in 1897. For further discussion, see John Witt, Widows, Actuaries, and the Logic of Social Insurance, The Accidental Republic, 127-51, esp. at 139-41 (2004) (discussing this passage from Holmes in connection with the rise of a statistical approach to thinking about accidents and the rise of workers' compensation schemes).

3360 Mass. (6 Cush) 292 (1850). 
JOURNAL OF ETHICS \& SOCIAL PHILOSOPHY $\mid$ VOL. 2, NO. 1

STRICT LIABILITY AND THE MITIGATION OF MORAL LUCK

Gregory C. Keating

risks independent and uncorrelated, liability rules shift — but do not disperse - losses. In this world, the imposition of strict liability on reciprocal risks merely "substitute[s] one form of risk for another — the risk of liability for the risk of personal loss," as George Fletcher says in his famous paper on fairness and utility in tort theory. ${ }^{34} \mathrm{~A}$ fair distribution of the costs of accidents - of harm - is hard to come by because the distribution of the costs of accidents across the activities that generate them depends upon the underlying activity satisfying basic criteria of insurability. Foremost among these criteria is the law of large numbers. In the purest form of the "world of acts," both actors and activities are small.

At the opposite pole from the "world of acts" is the "world of activities." In the "world of activities," risks are generalized and systemic. Systemic risks arise out of a continuously repeated activity (the manufacture of Coke bottles, the supplying of water by a utility, the transport of gasoline) that is actuarially large. "Accidental" harm is statistically certain to result from such risks: If you make enough Coke bottles some are sure to rupture; if you transport enough gasoline, some tankers are sure to explode; if you leave water mains uninspected in the ground long enough, some are sure to break; if you turn enough sailors loose on shore leave, some of them are bound to return to their ships drunk and wreak havoc en route. In the "world of activities," both actors and activities are large. The cost of accidents can therefore be dispersed and distributed.

In the "world of activities," the typical injury arises not out of the diffuse and disorganized acts of unrelated individuals or small firms, but out of the organized activities of firms that are either large themselves, or small parts of relatively well-organized enterprises. The waterworks which is the defendant in Lubin v. Iowa City is large in the first sense: A single entity is responsible for the piping of water through underground pipes, for laying and maintaining those pipes, for charging consumers for the water so transported, and so on. The transportation of large quantities of gasoline in tractor trailers on highways is large in the second sense: The firms that do the transporting may (or may not be) small and specialized, but they are enmeshed in contractual relationships with those who manufacture and refine the gasoline, those who operate gasoline stations, those who manufacture tractor trailers, and so on.

In the "world of activities," accidental harms can be spread across the enterprises that engender those harms. When the law of large numbers is met, risks are not only certain to issue in harms, but they are also very likely to issue in harms with predictable regularity. When activities are actuarially large, the accidents that they engender will likewise be predictable and regular, and the costs of those accidents can be factored into the costs of con-

${ }^{34}$ George Fletcher, Fairness and Utility in Tort Theory, 85 Harv. L. Rev. 537, 547 (1972). 
JOURNAL OF ETHICS \& SOCIAL PHILOSOPHY | VOL. 2, NO. 1

STRICT LIABILITY AND THE MITIGATION OF MORAL LUCK

ducting the enterprise. The costs of manufacturing and distributing Coke can include the costs of injuries from exploding Coke bottles; the costs of supplying water to households and businesses can include the costs of the damage caused by broken water mains.

The move from the "world of acts" to the "world of activities" thus changes the question of fairness presented by the imposition of strict liability on fairly distributed risks. In the "world of acts," strict liability, as George Fletcher says, "merely substitutes the risk of liability for the risk of loss" — it yields a different, but no fairer, distribution of the financial burdens and benefits of accidental harm. In the "world of acts," negligence is preferable to strict liability because negligence reconciles the competing claims of liberty and security as fairly and less expensively than strict liability does. In the "world of activities," strict - enterprise - liability is fairer than negligence. Under enterprise liability, those who benefit from the imposition of particular systemic risks - from the risks of selling Coke in pressurized bottles, or the risks of leaving water mains undisturbed until they break - also bear the financial burdens of the accidents that issue from these risks. In the "world of activities," unlike the "world of acts," the extra burdens that strict liability places on the liberty of injurers are less than the extra burdens than negligence places on the security of victims. Negligence leaves concentrated harms on injurers; enterprise liability disperses concentrated loss and distributes it across all the beneficiaries of an enterprise.

In the "world of acts," it is unreasonable to impose strict liability on risks that potential injurers and victims impose equally on each other. In a world of unorganized risk, it is not possible to distribute (the financial costs of) harm fairly, and reasonable injurers may object that the move to strict liability imposes as great a burden on their freedom of action as negligence imposes on the security of victims. Under negligence, the concentrated costs of non-negligent accidents strike victims like lightning; under strict liability those costs strike injurers like lightning. Because strict liability yields a distribution of accident costs which is no fairer than the distribution under negligence liability, it is reasonable to maximize the size of the pie by preferring the cheaper liability regime. In the world of activities, by contrast, the burdens are asymmetrical. Enterprise liability distributes the costs of nonnegligent accidents through injurers across those who benefit from the underlying risks. Negligence liability leaves the costs of those accidents concentrated on unlucky victims. It may be rational to want to reap the benefits of a risky common enterprise without sharing in its burdens, but it is not reasonable to do so. 
JOURNAL OF ETHICS \& SOCIAL PHILOSOPHY | VOL. 2, NO. 1

STRICT LIABILITY AND THE MITIGATION OF MORAL LUCK

Gregory C. Keating

\section{The Facets of Fairness}

The fairness case for enterprise liability is not fully captured by the statement that it distributes the costs of accidents across those who benefit from the underlying risks. Indeed, four distinct facets of the fairness case for enterprise liability can be distinguished. The first of the four facets of enterprise liability fairness is fairness to victims. It is unfair to concentrate the costs of characteristic risk on those who simply happen to suffer injury at the hands of such risk, when those costs might be absorbed by those who impose the characteristic risk. Fairness prescribes proportionality of burden and benefit. Victims who are strangers to the enterprise derive no benefit from it and it is therefore unfair to ask them to bear a substantial loss when that loss might be dispersed across those who participate in the enterprise and therefore do benefit from it. Victims who are themselves participants in an enterprise share in its benefits, but not in proportion to the detriment they suffer when they are physically harmed by the enterprise. Here, too, enterprise liability is fairer than negligence. It disperses the costs of enterprise-related accidents and distributes them within the enterprise, so that each bears a proportionate share.

Second, enterprise liability is fair to injurers because it simply asks them to accept the costs of their choices. Those who create characteristic risks do so for their own advantage, fully expecting to reap the benefits that accrue from imposing those risks. If those who impose characteristic risks choose wisely - if they put others at risk only when they stand to gain more than those they put in peril stand to lose - even under enterprise liability they will normally benefit from the characteristic risks that they impose. If they do not, they have only their poor judgment to blame, and society as a whole has reason to penalize their choices. The Coast Guard lets its sailors loose on shore leave for its own benefit (as well as for theirs) and it reaps the rewards of their shore leave. If the costs of shore leave are greater than the benefits, the Coast Guard has only itself to blame for the practice and society has reason to discourage it. Imposing risks whose expected costs exceed their expected benefits is negligence.

The conception of responsibility invoked in the last paragraph is a familiar and widely accepted one. We take it for granted, for example, that "the person to whom the income of property or a business will accrue if it does well has normally also to bear the risk of loss if it does badly. In the law of sales, when the right to income or fruits passes to the buyer, the risk of deterioration or destruction normally passes to him as well." 35 The same point might be made about the purchase of stocks, or even lottery tickets. It is fair to ask agents who choose to act in pursuit of their own interests and stand to

35Tony Honore, Responsibility and Fault 79 (1999). 
JOURNAL OF ETHICS \& SOCIAL PHILOSOPHY | VOL. 2, NO. 1

STRICT LIABILITY AND THE MITIGATION OF MORAL LUCK

profit if things go well to bear the risk of loss when things go badly. Enterprise liability is fair to injurers.

Third, enterprise liability is fair because it exacts a just price from injurers for the freedom tort law confers upon them. Tort law permits potential injurers to put others at risk without their knowledge or consent, and for the private benefit of potential injurers. Indeed, tort law requires potential victims to entrust their lives and limbs to persons and entities who stand to profit by imperiling them. This power is of great value to potential injurers: They stand to reap rewards by imposing risks, in part, because they can choose to impose those risks in circumstances that maximize the benefit they gain from doing so. The price that enterprise liability exacts for this freedom and power is financial responsibility for physical harm, when that harm is characteristic of the injurer's activity. To induce potential injurers to exercise their power over others responsibly — and to safeguard the security of those others enterprise liability taxes the exercise of the power to put others at risk when it goes awry and issues in physical harm.

Negligence liability taxes the exercise of the power to imperil others only when the injurer has exercised that power without sufficient care. ${ }^{36}$ Accidental harms attributable to activities that are conducted carefully, but at an excessively high level of intensity, or without undertaking justified research that would yield safer ways of proceeding, tend to escape the reach of negligence liability. Strict accountability induces potential injurers - particularly large enterprises - to conduct their activities more safely. By taxing every exercise of the power to imperil others that issues in an accident characteristic of the enterprise in question, enterprise liability induces injurers to comb through their activities in search of risk-reducing precautions. Worthwhile precautions whose omission escapes the eye of negligence law may be induced by the imposition of enterprise liability.

The fourth facet of fairness returns us to the general idea of burdenbenefit proportionality: Enterprise liability distributes accident costs among actual and potential injurers more fairly than negligence does. Negligence liability does not require that the costs of accidents - even negligent ones — be spread among those who create similar risks of harm, whereas enterprise liability does. Enterprise liability asserts: (1) that accident costs should be internalized by the enterprise whose costs they are; and (2) that those costs should be dispersed and distributed among those who constitute the enterprise, and who therefore benefit from its risk impositions. Negligence liability, by contrast, holds that injurers have a duty to make reparation when they injure others through their own carelessness. Negligence liability justifies shift-

${ }^{36}$ The ideas in this paragraph draw on Shavell, Negligence Versus Strict Liability, 9 J. Leg. Stud. 1 (1980) and Guido Calabresi \& Jon T. Hirschoff, Toward a Test for Strict Liability in Tort, 81 Yale L.J. 1055 (1972). 
JOURNAL OF ETHICS \& SOCIAL PHILOSOPHY | VOL. 2, NO. 1

STRICT LIABILITY AND THE MITIGATION OF MORAL LUCK

Gregory C. Keating

ing concentrated losses where enterprise liability justifies dispersing and distributing concentrated losses. To be sure, nothing in negligence liability forbids injurers from insuring against potential liability, but nothing in negligence liability requires it, either. Insurance is not integral to negligence liability, even though insuring against negligence liability is standard modern practice.

It is, moreover, important in this regard that insuring against negligence liability makes negligence liability fairer precisely because it moves negligence toward enterprise liability. Negligence liability is often harsh, and problematically so. ${ }^{37}$ In part, negligence law is harsh because it justifies shifting potentially devastating losses from injurers to victims on the basis of relatively modest acts of wrongdoing. A moment's carelessness behind the wheel of a car can inflict millions of dollars of harm, and that is enough to bankrupt most drivers. The price that negligence liability exacts can thus seem quite disproportionate to the wrongfulness of the conduct whose blameworthiness justifies the exaction. The ordinary negligence of natural persons is a relatively innocent sort of wrongdoing: The failure to foresee a risk clearly enough, calculate its probability accurately enough, concentrate well enough, or execute a course of action precisely enough, are all instances of ordinary negligence. We are all prone to such mistakes, human frailty being what it is. Yet negligence law is unforgiving. Failures to act as a reasonable person would act in similar circumstances are enough to support liability, even if those failures are the product of normal human frailty. And the extent of the ensuing liability can be devastating.

So long as we restrict our gaze to the apportionment of costs between a particular injurer and the victim of her negligence, negligence law is exacting and intolerant, but justifiably and fairly so. The activities that negligence liability regulates are unforgiving. Small mistakes can explode into serious injuries. Momentary lapses of attention behind the wheel of a car — or at the helm of a ship or the controls of a plane - can and do destroy human lives. The seriousness of the harm risked by ordinary negligence is good reason to hold actors to strict standards of conduct. And the failure to conform to a norm of reasonable care is a kind of wrongdoing, even if not a particularly egregious one. Wrongdoing fairly exposes wrongdoers to responsibility to repair the harm that they have done. Forgiving wrongful lapses in concentration and failures of foresight would allocate the losses these frailties cause even more unfairly. Why should injured victims absorb the costs of the carelessness that harmed them? Shifting the costs of a negligent injury to the wrongdoer whose inadvertence caused it may be harsh, but it is fairer than letting the loss lie where it fell. Finally, forgiving lapses in concentration and

37"Average reasonable person" doctrine shows this side of negligence liability most clearly. See Keeton, et al., Tort and Accident Law 345-368 (4th ed. 2004). Prosser \& Keeton on the Law of Torts, 173-193 (4th ed. 1984). 
JOURNAL OF ETHICS \& SOCIAL PHILOSOPHY | VOL. 2, NO. 1

STRICT LIABILITY AND THE MITIGATION OF MORAL LUCK

Gregory C. Keating

failures of foresight might well encourage carelessness. Forbearance tends to foster the objects of its indulgence.

Holding actors accountable for the harmful consequences of their understandable errors is, then, fairer than excusing them. But this does not settle all questions of fairness, nor undermine the argument that enterprise liability is fairer still. The small lapses that very occasionally precipitate large injuries are common indeed. Most of us occasionally let our minds wander behind the wheel, give some small risk insufficient consideration, or fail to execute some all too familiar precaution with the precision that it requires. Most of us also escape without injuring anyone else. Yet the luck of the draw is all that distinguishes those of us who get away without injuring anyone from those who do not. Fate singles an unlucky few out for liability - often massive liability — and fortune spares the rest.

Those unlucky few who inflict injury cannot, on balance, claim that they are unjustly held accountable for the harm that their wrongdoing has caused, but they might justly complain that a system under which they alone bear the costs of the injuries they inflict is less fair than one which pools those losses among all those who create similar negligent risks. ${ }^{38}$ Negligence mitigated by the institution of liability insurance is fairer than negligence detached from that institution. Liability insurance distributes the costs of negligence among all those who are, over the long run, similarly negligent, and that is fairer than leaving the costs of negligence on those whose misfortune it is to have their negligence issue in injury. Luck, and luck alone, separates the negligent who cause injury from the negligent who do not. It is fairer to neutralize the arbitrary effects of luck than to let it wreak havoc with people's lives.

Just as negligence with the institution of liability insurance is fairer among actual and potential victims than negligence liability without that institution is, so too enterprise liability is fairer than negligence liability with insurance. Once negligence liability operates against the background of liability insurance, all that divides it from enterprise liability is its treatment of those accident costs that flow from reasonable risk impositions. Both negligence liability and enterprise liability pool the accident costs that issue from negligent risk impositions among those who are similarly negligent. Negligence liability, however, leaves the non-negligent accident costs of an activity on

${ }^{38}$ They might also complain that their liability under negligence is out of proportion to their culpability. When corrective justice violates the retributive principle that the penalty should be proportional to the wrong, corrective justice violates our sense of justice. See Jeremy Waldron, Moments of Carelessness and Massive Loss, supra note at 389-91 (voicing this kind of objection) and at 401-405 (discussing whether a form of fault-based corrective justice which concentrates devastating losses on the unlucky few can be justified as fair by an application to tort law of David Lewis' defense of criminal liability as a penal lottery); Tony Honore, Responsibility and Fault, supra note, at 89-90 (arguing that corrective justice is flawed when it violates the retributive principle requiring a "rough proportion to be preserved between the degree of fault and the burden of the sanction.") 
JOURNAL OF ETHICS \& SOCIAL PHILOSOPHY | VOL. 2, NO. 1

STRICT LIABILITY AND THE MITIGATION OF MORAL LUCK

Gregory C. Keating

their victims, whereas enterprise liability distributes those costs across the enterprise - across all those who impose the characteristic risks that lead to these accidents. Under negligence liability, victims may disperse the costs of an activity's non-negligent accidents by purchasing loss insurance, but they will not distribute those costs across those who impose similar risks.

When reasonable risk results in accidental harm, chance and chance alone separates those who injure and are injured from those who do not and are not. To leave non-negligent losses on those whose misfortune it is to suffer them, when we might readily spread these losses among all those who create similar risks of injury, is unfair. When the concentrated costs of nonnegligent accident might easily be dispersed and distributed across those who benefit from the creation of the relevant risks, the victims of such accidents might reasonably object to a principle of responsibility that leaves the costs of those non-negligent accidents concentrated on victims. Those who benefit from the imposition of the relevant risks but escape injury at their hands, by contrast, cannot reasonably object to having non-negligent accident costs dispersed and distributed across all those who benefit from the imposition of the relevant risks. It may be rational to seek to appropriate the benefits of recurring risk imposition for oneself and to thrust the burdens of those risk impositions onto others, but it is not reasonable to do so.

Dispersing the non-negligent accident costs characteristic of an activity across pools of victims who are bound together only by their actuarial similarity is likewise less reasonable than dispersing them across the injurers who create similar risks and benefit from doing so. People who do not benefit from an activity may reasonably object to bearing its costs when those who do benefit might be made to bear its costs with equal ease. In short, fairness favors dispersing the costs of blameless accidents among all those who create similar risks of such accidents, just as much as it favors dispersing the costs of accidents precipitated by wrongdoing among lucky and unlucky wrongdoers. Pooling the risks of negligent accidents, but not the risks of nonnegligent accidents, is presumptively less fair than pooling both sets of risks.

This last argument of fairness highlights both the fact that enterprise liability relaxes the requirement of causation, and also the fact that the logic of fairness at work in enterprise liability criticizes - as arbitrary and unfair the traditional tort insistence that a specific actor — not an activity - be held causally responsible for the harm. When cause and cause alone distinguishes those who injure from those who do not, luck and luck alone distinguishes those who bear liability from those who escape it. The requirement of causation cannot bear the weight of the justification that it must bear in these circumstances. There is no good reason why a person unfortunate enough to have her carelessness issue in massive injury should bear massive 
JOURNAL OF ETHICS \& SOCIAL PHILOSOPHY | VOL. 2, No. 1

STRICT LIABILITY AND THE MITIGATION OF MORAL LUCK

loss, while many others who have been identically culpable are spared all responsibility. ${ }^{39}$

This conclusion is resisted mightily by many (though not all 40 ) corrective justice theorists. Act causation, they insist, can be dispensed with only at the price of moral and conceptual incoherence. Ernest Weinrib - perhaps the pre-eminent proponent of this view - explains the assertion by saying: "Corrective justice involves the intrinsic unity of the doer and sufferer of the same harm." 41 Therefore, "the requirement that the defendant have caused the plaintiff's injury" is one of a handful of elements of tort liability whose absence marks "the disappearance of private law a recognizable mode of ordering." "When harms are attributed to activities, and losses distributed among all those who create the same characteristic risks, the unity of doing and suffering, corrective justice — and tort law itself — all disappear. ${ }^{43}$

Arthur Ripstein, writing in the same vein, criticizes Christopher Schroeder's and Jeremy Waldron's defenses of enterprise liability in these terms:

Like Schroeder, though, Waldron offers no explanation of why only those misfortunes brought about by carelessness are to be compensated in this way. In the attempt to avoid the supposed arbitrariness of chance, Waldron, like Schroeder, finds himself embracing the genuine arbitrariness of

${ }^{39}$ With small numbers, this is the lesson of Summers $v$. Tice, 33 Cal.2d 80, 199 P.2d 1 (1948).

${ }^{40}$ See Christopher H. Schroeder, Corrective Justice, Liability for Risks, and Tort Law, 38 UCLA L. Rev., 1431990 (arguing that corrective justice is perfected by dispensing with what might be called “act causation").

${ }^{41}$ Weinrib, supra note, at 75 . The idea that the doing and the suffering must be of the same harm warrants repetition.

${ }^{42} I d$. at 9. At pp. 1-2 Weinrib writes:

The most striking feature of private law is that it directly connects two particular parties through the phenomenon of liability. Both procedure and doctrine express this connection. Procedurally, litigation in private law takes the form of a claim that a particular plaintiff presses against a particular defendant. Doctrinally, requirements such as the causation of harm attest to the dependence of the plaintiff's claim on a wrong suffered at the defendant's hand.

${ }^{43}$ The great strength of this idea is that it provides an answer to the question: Why reparation? That answer is: because the person who has inflicted the harm stands in a special, morally salient relation to the victim of that harm. A weakness of this act-centered idea, however, is that it cannot account for the fact to which enterprise liability bears witness - the fact that the collective activity can be seen as standing in a more morally salient relation to the victim than the individual actor who inflicted the injury. 
JOURNAL OF ETHICS \& SOCIAL PHILOSOPHY $\mid$ VOL. 2, NO. 1

STRICT LIABILITY AND THE MITIGATION OF MORAL LUCK

Gregory C. Keating

selecting candidates for compensation based on how they came about while simultaneously denying the relevance of how they came about. ${ }^{44}$

There is, it seems, no conceptual space between traditional tort liability and universal social insurance. Enterprise liability cannot coherently exist.

Ripstein's objection misses its mark. We have perfectly good reason to distinguish between harmful human agency — the subject to which activity liability addresses itself - and fate (against whose perils social insurance protects us). "The nature of things," Rousseau famously remarked, "does not madden us, only ill will does." ${ }_{45}$ Natural misfortune is neither just nor unjust. It may be feared, but it is beyond the reach of resentment. Malfeasance is another matter. People do have reason to resent mistreatment at the hands of others. The institutions which determine the terms on which people may impose risks of serious physical injury on one another are concerned with harmful human agency, and harmful human agency is not something which can ever be a matter of moral indifference. ${ }^{46}$ The institutions of accident law are either just or unjust, and people have reason to resent injustice.

From here it is but a short step to the defense of strict liability. Strict liability identifies a distinct form of mistreatment: There are some harms which may only be justly inflicted if compensation is paid for damage done. Vincent v. Lake Eriet is a case in point. Neither Vincent nor Lake Erie have reason to resent the natural misfortune of the storm: Whom might they call to account? But Vincent does have reason to resent Lake Erie's failure to repair the harm done his dock by Lake Erie's ship. Even though Lake Erie was fully justified in lashing its ship to Vincent's dock and even though it was that justified action which damaged Vincent's dock, Lake Erie's infliction of damage to the dock was justifiable only on condition that Lake Erie repair the

${ }^{44}$ Ripstein, supra note, citing to Waldron, supra note.

45Jean-Jacques Rousseau, Emile, Book 2: vol. 4, p. 320 Oeuvres Complete (Bernard Gagnebin, et al., eds. 1959-95). Isaiah Berlin quotes this passage in his Two Concepts of Liberty, reprinted in I. Berlin, Four Essays on Liberty (1969).

${ }^{46}$ Honore, Responsibility and Fault, supra note, at 84. ("It seems reasonable to put conduct that exposes others to a risk that materializes — for example selling milk that may possibly be and in fact is adulterated - at a fairly low point on the scale of misconduct on which showing indifference to and defiance of the interests of others occupy the higher reaches. The behavior located low on the scale is not morally bad, and does not amount to fault, but neither is it morally indifferent; conduct that may affect others cannot be that. It is taking a chance of harming others." [fn. omitted])

47124 N.W. 221 (Minn. 1910). 
JOURNAL OF ETHICS \& SOCIAL PHILOSOPHY $\mid$ VOL. 2, No. 1

STRICT LIABILITY AND THE MITIGATION OF MORAL LUCK

damage done. ${ }^{48}$ Strict liability identifies a special kind of wrongdoing - a kind where the wrongfulness lies not in the infliction of the injury but in the failure to make reparation for an injury justifiably inflicted. This is a kind of malfeasance and - as Professor Ripstein himself has argued - there is a fundamental distinction between misfortune and mistreatment. ${ }^{49}$

Enterprise liability tends toward strict liability and, as a form of strict liability, it is distinctive in its focus on organized activities not individual acts. But there is nothing incoherent or mysterious about this. It arises out of the perception that the accidents characteristic of our social world are "mainly the incidents" of ongoing systematic activities. From here it is but a short step to the basic precepts of enterprise liability: (1) that, in characteristically modern circumstances, protection against enterprises takes priority over protection against individual actors; (2) that this protection can and should be secured by requiring enterprises to bear the costs of their characteristic risks; and (3) that it is fairer to distribute the costs of an enterprise's characteristic risks across the enterprise, than to leave them concentrated on the particular parties to enterprise-related accidents. One can contest these claims, but one cannot seriously dispute their coherence.

The complaint that we have lodged on Ernest Weinrib's behalf 50 — that enterprise liability denies the unity of doing and suffering as Weinrib understands it — is true but toothless. In the "world of activities," 51 doing and suffering simply are not unified in the way that Weinrib insists that they are. To be sure, actions can be described in all kinds of ways and it is not unintelligible to say that, between two equally careless drivers, the one who inflicts a devastating injury has done something entirely different from the one whose negligent risk has dissipated harmlessly, even if chance and chance alone ac-

${ }^{48}$ See Gregory C. Keating, Property Right and Tortious Wrong in Vincent v. Lake Erie, Issues in Legal Scholarship, Symposium on "Vincent v. Lake Erie Transportation Co. and the Doctrine of Necessity," Article 6 (2005).

${ }^{49}$ See Arthur Ripstein \& Jules Coleman, Mischief and Misfortune, 41 McGill L. J. 91 (1995).

${ }^{50}$ In a commentary on this paper at the conference, Martin Stone urged this kind of criticism. Stone is the author of two important papers on Weinrib's conception of corrective justice as embodied by tort law. See Martin Stone, The Idea of Private Law, supra note, and Martin Stone, The Unity of Doing and Suffering, in Philosophy and the Law of Torts (Gerald J. Postema ed., 2001).

${ }^{51}$ And perhaps in the world of risk imposition more generally. Weinrib adopts the expression and the idea from Aristotle. Tellingly, however, the only examples of Aristotle's that Weinrib cites to illustrate this unity are examples of intentional wrongs. "The injustice of battery and murder, for instance, (in Aristotle's words, 'when one has hit and the other has been hit, and when one has killed and the other has been killed'), lies in the fact that the doing and the suffering have been unequally divided." Weinrib, supra note, at 64, fn. omitted. Plainly, intentional hitting unifies doing and suffering in a way that imposing a risk of a blow to the head does not. 
JOURNAL OF ETHICS \& SOCIAL PHILOSOPHY $\mid$ VOL. 2, NO. 1

STRICT LIABILITY AND THE MITIGATION OF MORAL LUCK

Gregory C. Keating

counts for these wildly divergent outcomes. But though it is intelligible to say this, it is also utterly unpersuasive to speak this way. To impose a risk is to play a lottery. When you buy a lottery ticket, you place a bet and take your chances (and you almost always lose!). A lottery spokesman who talked about the "unity of purchasing and winning" would be courting liability for fraud. Purchasing is a necessary precondition of winning but no more. The two are disjoined far more often than they are unified.

When you impose a risk of serious physical injury on others, you take your chances in a different kind of lottery: You may inflict devastating injury or your risk may dissipate harmlessly. Usually — and fortunately — risks of devastating injury dissipate harmlessly. But whether such a risk devastates or dissipates is a matter of chance. Speaking of the "immediate relation" of doing and suffering in connection with the imposition of a risk is no more convincing than speaking of the "immediate relation" of purchasing and winning in connection with a lottery. ${ }^{52}$ The claim of "immediate relation" badly distorts our understanding of the two risk impositions it so radically distinguishes: The difference between two actors who impose identical risks, only one of which issues in devastating injury, is determined by the luck of the draw and the luck of the draw alone. To impose a risk is to roll the dice. Rolling the dice is not an action where the rolling and the result are one and the same action. It is thus a virtue, not a fault, of activity liability that it denies the unity of doing and suffering as Weinrib understands it. In the world of activities, accidents are characteristically connected to activities and only coincidentally correlated with individual acts.

\section{Mitigating Moral Luck}

In introducing the law of torts, it is common to say that it protects us against conduct that is both harmful and wrong. ${ }^{53}$ The framework sketched in this paper supposes that tort should fix its protections on terms that fairly reconcile the competing claims of liberty and security asserted by a plurality of equal and independent persons, who hold distinct and diverse ends.

${ }^{52}$ See Weinrib, supra note, at 81 for use of the term "immediate relation."

${ }^{53}$ For example, in the Introduction to his treatise on torts, Richard Epstein writes: "Every legal society from the most primitive to the most modern must develop some set of rules that prevents one individual from harming another. ..." Richard A. Epstein, Torts, xxvii (1999). In the first section of his treatise Dan Dobbs writes: "A tort is conduct that amounts to a legal wrong and that causes harm for which courts will impose civil liability." Dan B. Dobbs, The Law of Torts, 1 (2000). In point of fact, harm is not an element of every tort. Trespass to land and conversion are cases in point. Generally speaking, when harm is not an element of a tort, the tort is based on a right (e.g., on the right to exclude others from entry onto one's real property). Most torts, however, are predicated on the wrongful conduct of the defendant and that wrongful conduct usually involves the infliction of injury. 
JOURNAL OF ETHICS \& SOCIAL PHILOSOPHY $\mid$ VOL. 2, NO. 1

STRICT LIABILITY AND THE MITIGATION OF MORAL LUCK

Wrongful conduct on this view is conduct that strikes an unjust balance between the competing claims of liberty and security. Within the law of torts, then, the problem of moral luck is a second-order one - neutralizing the effect of luck on responsibility for harm done is not and should not be a fundamental objective of the law of torts. But the problem of moral luck cannot be wholly ignored either. Within ordinary moral thinking, the problem of moral luck arises naturally, as Thomas Nagel says:

The erosion of moral judgment [by the phenomenon of moral luck] emerges not as the absurd consequence of an over-simple theory, but as a natural consequence of the ordinary idea of moral assessment, when it is applied in view of a more complete and precise account of the facts. . . . The view that moral luck is paradoxical is not a mistake, ethical or logical, but a perception of one of the ways in which the intuitively acceptable conditions of moral judgment threaten to undermine it all. ${ }^{54}$

In tort, the problem is not the erosion of confidence in moral judgments of culpability, but the erosion of confidence in the justice of negligence liability. But this erosion, too, comes about from the application of intuitively acceptable ideas.

Chief among these intuitively acceptable ideas are the propositions that liability should turn on what people have done (culpably or faultlessly) and that "like cases should be treated alike." The first idea is firmly fixed in our intuitions about the bases of responsibility for harm done. Responsibility for harm done is the subject matter of torts and it seems almost tautological to say that to be responsible for harm done one has to do it. When two similarly situated negligent actors are divided only by luck — when the negligence of one has unfortunately resulted in injury, whereas the identical negligence of the other has fortuitously resulted in no harm at all — our confidence that we are imposing liability for harm done by the first actor is shaken. The harm seems to be done by luck. The second idea - that "like cases should be treated alike" - in its turn is a fundamental precept of justice according to law. ${ }^{55}$ When fate singles out one careless actor for crushing liability and fortune spares her equally careless companion, the precept that like cases should be treated alike casts doubt on the justice of negligence liability. A form of liability which is subject to these anomalies is less disquieting and more defensible. Strict enterprise liability is such a form. By pooling accident costs among those who create the risks responsible for them, strict enterprise liability treats the competing claims of the lucky and the unlucky more fairly,

${ }^{54}$ Nagel, supra note, at 27.

${ }^{55}$ H.L.A. Hart, The Concept of Law, 157-67 (2d. ed. 1994). Compare Waldron, supra note, at 390-91 (noting how the distinctions drawn by negligence liability and defended by corrective justice theorists violate our ordinary criteria of fairness and desert). 
JOURNAL OF ETHICS \& SOCIAL PHILOSOPHY $\mid$ VOL. 2, NO. 1

STRICT LIABILITY AND THE MITIGATION OF MORAL LUCK

Gregory C. Keating

and diminishes the role of moral luck. Other things equal, this feature of strict enterprise liability makes it less disquieting and more defensible than negligence.

There is a broader lesson lurking as well: When we speak of the effects of moral luck on responsibility in law, we are speaking of something which is shaped by human artifice - by the design of legal institutions. The moral luck that figures so vividly in negligence liability is not merely the consequence of applying our ordinary notions of moral assessment to accidental harm. It is also a consequence of the way in which negligence liability attributes responsibility for harm done. Negligence liability is prone to hunt for individual fault in institutional settings. ${ }^{56}$ It tends to attribute accidents which are characteristic of institutions to particular individuals. The erosion of confidence in the justice of negligence liability associated with the play it gives to moral luck is, in important part, a consequence of the mismatch of liability regime and social reality.

In the modern "world of activities," accidents are not the random byproducts of discrete individual acts, but the regular and predictable consequences of large activities, enduring over time. It is a matter of luck just which agent within such activities will inflict injury - negligently or faultlessly - but it is not a matter of luck that injuries will be inflicted. That injuries will be inflicted is a matter of the actuarially certain consequences of human agency, expressed collectively. The closer our social world draws to the pure type of the "world of activities," the more fully we know not just that accidents are certain to happen, but how frequently they are certain to happen. The closer our social world draws to the pure type of the "world of activities," the more it is the case that collective agency, not luck, is dealing out death and devastation. In this world, negligence liability exacerbates the problem of moral luck that strict enterprise liability mitigates.

Tort law may thus have something to tell us about the sources of moral luck. Toward the end of his paper, Thomas Nagel muses that the problem of moral luck may arise out of our ability to adopt both objective and subjective perspectives toward ourselves - to see ourselves both as objects within the natural world, governed by causal laws, and as actors who cannot help but

${ }^{56}$ This is vividly illustrated by the application of the doctrine of conditional res ipsa in Ybarra v. Spagnard, 25 Cal.2d 486, 154 P.2d 687 (1944). Plaintiff experienced a serious injury to his shoulder and neck immediately following surgery for an appendectomy. Convinced that someone's malfeasance in the operating room was responsible for this condition, the court permitted a conditional res ipsa instruction to be introduced against all the defendants. When no defendant was able to meet the burden of proof of exculpating him or herself, judgment was entered against all of them. It later came to appear that the injury was unrelated to the surgery. It would be both administratively easier and morally more apt to ask an enterprise liability question instead of an individual fault one: Was the injury attributable to the operation? This is administratively easier because it simplifies the inquiry. It is morally more apt because the surgery was a collective enterprise. 
\begin{tabular}{l|l} 
JOURNAL OF ETHICS \& SOCIAL PHILOSOPHY & VOL. 2, No. 1
\end{tabular}

STRICT LIABILITY AND THE MITIGATION OF MORAL LUCK

conceive of ourselves as free. In tort law, the phenomenon appears to arise more proximately from another source: the clash of individual conceptions of fault with the reality of systemic social risk. What is luck to the parties involved, is statistically inevitable harm to the activity within which the accident arises. "Moral luck" is not "luck" at all, but the upshot of a mismatch of social reality and institutional form.

And this suggests one last lesson: The standard criticism of strict liability has it exactly backward. This criticism asserts that strict liability is suspect because of the great burden that it places on our freedom: We may find ourselves liable for devastating injury no matter how carefully we proceed, no matter how irreproachably we conduct ourselves. Strict liability is a sword of Damocles dangling over all of our actions. When the subject under consideration is strict enterprise liability in the law of torts - and when that subject is under consideration in "a world of activities" - this criticism is wholly misplaced. In the "world of activities," strict enterprise liability protects our freedom of action, whereas fault liability heightens our exposure to unavoidable financial ruin. By substituting certain but manageable insurance premiums for unpredictable but potentially catastrophic liability and more certain compensation for harm suffered for less certain compensation, strict liability enhances both liberty and security.

Gregory C. Keating

University of Southern California

Gould School of Law

gkeating@law.usc.edu 